UDC 94(477)

Submitted: 09.12.2019

LBC 64.4(0)

Accepted: 07.04.2020

\title{
THE NUNN-LUGAR PROGRAM AND NUCLEAR DISARMAMENT OF UKRAINE
}

\author{
Sergey Yu. Shenin \\ Saratov National Research State University named after N.G. Chernyshevsky, Saratov, Russian Federation
}

\author{
Andrei S. Shenin \\ Narxoz University, Almaty, Republic of Kazakhstan
}

\begin{abstract}
Introduction. This article is devoted to studying the process of nuclear disarmament of Ukraine in the framework of the Nunn-Lugar Program in the first half of the 1990s. The reconstruction of this process makes it possible to determine specific features of the Ukrainian disarmament and demonstrate the absence of alternatives for it. Methods and materials. The paper is based on the latest U.S. declassified documents, regulatory and legal acts, memoirs, etc. The author uses historical and systemic methods to research the stages of the evolution of the nuclear disarmament process in Ukraine and study politicians attitudes towards the Soviet nuclear legacy. Analysis and results. The study investigates the reasons for joining the efforts of Moscow and Washington in turning Ukraine into a "nuclear-free state", reveals the Russian and American attitudes towards the problem. Particular attention is paid to contradictions within the Ukrainian political elite that was split into the "pro-nuclear" and "antinuclear" groups. The article also studies the role of President L. Kravchuk in solving the disarmament problem, which was extremely contradictory. Finally, the article analyzes the reasons that allow to change the balance of political forces in Ukraine in favor of the "anti-nuclear" group, which enabled president Kravchuk to reaffirm his international obligations and initiate the nuclear disarmament process. In general, the article shows that the preservation of nuclear weapons by Ukraine was impossible due to a number of financial, technological, and geopolitical reasons.

Key words: nuclear disarmament, Ukraine, Russia, United States, Nunn-Lugar program, Budapest memorandum, START-1, Lisbon protocol.

Citation. Shenin S.Yu., Shenin A.S. The Nunn-Lugar Program and Nuclear Disarmament of Ukraine. Vestnik Volgogradskogo gosudarstvennogo universiteta. Seriya 4. Istoriya. Regionovedenie. Mezhdunarodnye otnosheniya [Science Journal of Volgograd State University. History. Area Studies. International Relations], 2020, vol. 25, no. 3, pp. 103-114. (in Russian). DOI: https://doi.org/10.15688/jvolsu4.2020.3.9
\end{abstract}

УДК 94(477)

ББК 64.4(0)

Дата поступления статьи: 09.12.2019 Дата принятия статьи: 07.04.2020

\section{«ПРОГРАММА НАННА - ЛУГАРА» И ЯДЕРНОЕ РАЗОРУЖЕНИЕ УКРАИНЫ}

\section{Сергей Юрьевич Шенин}

Саратовский национальный исследовательский государственный университет им. Н.Г. Чернышевского, г. Саратов, Российская Федерация

\section{Андрей Сергеевич Шенин}

Университет Нархоз, г. Алматы, Республика Казахстан

Аннотация. Данная статья посвящена изучению процесса ядерного разоружения Украины в рамках «программы Нанна - Лугара» в первой половине 1990-х годов. Реконструкция данного процесса дает возможность выявить особенности ликвидации ядерного оружия на Украине и показать ее безальтернативность. На основе новейших рассекреченных документов исполнительной власти США, нормативных и правовых актов, мемуаров и т. д. в исследовании показаны причины объединения усилий Москвы и Вашингтона 
в деле превращения Украины в «безьядерную державу». Так, США исходили из угрозы расползания ядерных материалов и безопасности их уничтожения в РФ. В России считали, что Киев технически не в состоянии решить задачу ликвидации боеголовок, а кроме того, может попытаться взять их на вооружение своей армии. Особое внимание в статье уделено противоречиям внутри украинской политической элиты. Так, «проядерная» группировка настаивала на собственности Украины на боеголовки, а «антиядерная» группа полагала, что их сохранение приведет к изоляции страны. Также в статье анализируется роль президента Л. Кравчука, которая отличалась крайней противоречивостью. Наконец, в статье анализируются причины, позволившие изменить баланс политических сил на Украине в пользу сторонников «антиядерной» позиции, что дало возможность президенту подтвердить свои международные обязательства и инициировать начало процесса ядерного разоружения страны. В целом в статье показано, что сохранение Украиной ядерного оружия было невозможно в силу целого ряда причин финансового, технологического, геополитического характера. Вклад авторов: А.С. Шенин собрал документы в архивах США, а также подготовил базовую версию статьи; С.Ю. Шенин сформулировал основные выводы и подготовил статью к публикации.

Ключевые слова: ядерное разоружение, Украина, Россия, США, «программа Нанна - Лугара», Будапештский меморандум, СНВ-1, Лиссабонский протокол.

Цитирование. Шенин С. Ю., Шенин А. С. «Программа Нанна - Лугара» и ядерное разоружение Украины // Вестник Волгоградского государственного университета. Серия 4, История. Регионоведение. Международные отношения. - 2020. - Т. 25, № 3. - C. 103-114. - DOI: https://doi.org/10.15688/jvolsu4.2020.3.9

Введение. Процесс ядерного разоружения Украины в первой половине 1990-х гг. в рамках «программы Нанна - Лугара» является одним из ключевых, но недостаточно изученных эпизодов формирования системы международных отношений на пространстве бывшего СССР. Его реконструкция позволяет выявить особенности процесса ликвидации ядерного оружия на Украине, показать ее безальтернативность, а также лучше понять причины российско-украинских противоречий на современном этапе.

Методы и материалы. Для решения поставленной научной задачи важнейшее значение имеют исторический и системный методы. Так, линейность и структурированность в хронологическом порядке позволяет лучше понять закономерности эволюции процесса разоружения; системность в оценке событий со стороны политиков России, Украины и США дает более полную картину эволюции взглядов на вопрос о судьбе советского ядерного оружия после распада СССР. В работе использовался круг источников, среди которых наиболее важными были недавно рассекреченные в США архивные документы, аналитические отчеты Конгресса, мемуары участников, аналитические доклады по «программе Нанна - Лугара».

Анализ. После распада СССР в начале 1990-х гг. США столкнулись с опаснейшей проблемой: ядерное оружие осталось в руках бывших советских республик (России, Казах- стана, Белоруссии и Украины), которые переживали острые экономические и политические кризисы. Неблагополучная обстановка серьезно повышала возможность его попадания в руки «неблагонадежных» стран и международных террористических организаций.

В связи с этим США начали разработку специальной программы, направленной на контроль и недопущение распространения ядерного оружия из стран бывшего СССР, которая получила название «Совместное сокращение угрозы» или «программа Нанна - Лугара» (по имени инициировавших ее законодателей). В программе, одобренной Конгрессом в ноябpe 1991 г., указывалось, что на постсоветском пространстве основную роль в деле контроля за нераспространением ядерного оружия должна была играть Россия - как правопреемница Советского Союза, а также как страна, обладавшая необходимыми производственными мощностями для демонтажа ракет и переработки ядерных материалов. Целью «сокращения угрозы» являлся вывоз всего ядерного оружия с мест дислокации в бывших советских республиках на демонтаж и переработку в Россию, ликвидация инфраструктуры ядерных объектов и продажа переработанного ядерного топлива на мировом рынке с возвратом компенсации республикам либо деньгами, либо в виде топливных элементов для АЭС. Финансирование программы брали на себя США.

Практически в то же время и в том же направлении действовала группа «беловежс- 
ких» политиков. 30 декабря 1991 г. в Минске они подписали соглашение «О ядерных стратегических силах», в котором указывалось, что Россия, Украина и Белоруссия признают необходимость сохранения единого контроля над ядерным оружием. Особо подчеркивалось, что ядерное оружие, размещенное на территории Украины, должно находиться под контролем Объединенного командования Стратегических сил СНГ с целью его разукомплектования до конца 1994 г., в том числе тактического ядерного оружия до 1 июля 1992 года.

В начале 1990-х гг. «программа Нанна Лугара» была оперативно реализована на территориях Казахстана и Белоруссии. Расходы на работы в Казахстане составили порядка 285 млн долл., а в Белоруссии было потрачено около 240 млн долл. [23, с. 407, 408]. Что касается Украины, то ее руководство внезапно заявило о своем праве на ядерное оружие и желании производить его демонтаж на своей территории.

Первоначально ни США, ни Россия не видели особых проблем с ядерным разоружением Украины, поскольку в начале 1990-х гг. Верховная Рада, правительство и президент Леонид Кравчук твердо следовали «безъядерным» курсом. В середине 1991 г. украинский президент на встрече с американским дипломатом Ф. Зеликовым подтвердил важнейшие аспекты разоружения: Украина намерена стать безъядерным государством и поддержит идею централизованного контроля за ядерным оружием в рамках СНГ [17].

После этой встречи, убеждая представителей Совета национальной безопасности США в том, что Украина готова к ядерному разоружению, Ф. Зеликов указывал, что Киев подписал все важнейшие документы, касающиеся ядерного вопроса. Сюда относились, вопервых, декларация о государственном суверенитете Украины, где поддерживались три ядерных принципа (не производить, не обладать, не ввозить); во-вторых, соглашение о создании СНГ, где присутствовало требование о соблюдении СНВ-1; в-третьих, подписанные в Минске и Алма-Ате документы о едином контроле и разукомплектовании ядерного оружия [16].

Развивая этот тренд, 23 мая 1992 г. президент Л. Кравчук подписал Лиссабонский протокол, который являлся дополнительным соглашением к CHВ-1. Протокол оговаривал обязательства Украины, Белоруссии и Казахстана в кратчайшие сроки ликвидировать ядерное оружие и присоединиться к ДНЯО. Таким образом Украина становилась «неядерной» стороной договора СНВ-1. Наконец, оптимизма американским и российским политикам добавлял и тот факт, что к середине 1992 г. Украиной все тактическое ядерное оружие было передано Российской Федерации (правда, не совсем понятно в рамках каких механизмов [1]).

Однако параллельно с усилиями Л. Кравчука в украинском политическом истеблишменте активизировались националистические группы, которые противились вывозу боеголовок с территории страны. Они полагали, что «без ядерного оружия с Украиной не будут считаться», «у нас хотят обманом забрать нашу ядерную мощь», «иностранные расчеты компенсации за ядерное оружие - обман и мошенничество», а вся финансовая помощь и интерес к Украине немедленно прекратятся после его вывоза. Особое негодование у украинских националистов вызывала роль России, которая взяла на себя все права бывшей сверхдержавы, в том числе и на оружие массового поражения, оставшееся на территории постсоветских республик [12].

Украине было за что бороться. Ядерный потенциал Украины состоял из 130 твердотопливных ракет CC-19C; 46 твердотопливных ракет CC-24 MOD 2S; 176 шахтнопусковых установок; 40 тяжелых бомбардировщиков; от 1514 до 2156 стратегических ядерных боезарядов; от 2800 до 4200 тактических ядерных боезарядов. В сумме ядерная мощь Украины превышала потенциал Франции, Великобритании и Китая вместе взятых. По расчетам украинских специалистов, выступавших за сохранение ядерного оружия, в этом арсенале содержалось от 80 до 108 т высокообогащенного урана и от 57 до 95 т плутония, что стоило на тот момент от 50 до 100 млрд долл. [5, с. 121]. Правда, «пророссийские» эксперты называли другие цифры - 1,5 млрд долл. за 60 т высокообогащенного урана (ВОУ) и 1 млрд долл. за продажу низкообогащенного урана (НОУ) на мировом рынке [5, с. 148]. 
В то же время ведущие игроки на мировой «ядерной» арене - Россия и США имели свои взгляды на потенциал Украины, считая, что глобальная безопасность важнее, чем укрепление статуса и экономики новообразованного государства.

Позиция Москвы по данному вопросу была однозначной - после подписания международных договоренностей все тактическое и стратегическое ядерное оружие должно быть вывезено на переработку в Россию в обмен на «мирный дивиденд» из 3400 твердотопливных элементов (ТВЭЛ) для украинских АЭС и денежную компенсацию за продажу части ядерных материалов [14, с. 2-7]. Вдобавок, Москва совместно с Вашингтоном готовы были предоставить Киеву гарантии безопасности сразу же после ратификации CHB-1 и Лиссабонского протокола [10]. Разукомплектование ракет на территории Украины называлось Россией невозможным, поскольку ядерное оружие было произведено на советских предприятиях и являлось секретом России как правопреемницы СССР. Кроме того, Украина не обладала ни средствами, ни специалистами, ни производственными мощностями для переработки плутония ВОУ в $\mathrm{HOV}$, который в дальнейшем можно использовать в качестве топлива для АЭС. Отсутствовало также достаточное количество емкостей для слива чрезвычайно токсичных компонентов ракетного топлива (гептила и амила), не было технологий их переработки.

Тем не менее, как отмечал начальник 12-го Главного управления РФ Е. Маслин, Украина сохраняла достаточный интеллектуальный потенциал, чтобы вместо разбора боеголовок обойти кодовые блокирующие устройства и поставить ядерное оружие себе на службу. Правда, большие сомнения вызывала способность Киева обеспечить надежную систему управления и безопасности ядерного арсенала [6].

Похожей позиции придерживались и США. «На Украине нет ни технологий, ни мощностей, ни технических экспертов для реализации мероприятий по ядерному разоружению. Создание необходимых мощностей для разоружения потребует существенной помощи от Запада и технической поддержки от России, а их строительство займет, по край- ней мере, от 6 до 8 лет и обойдется в миллиарды долларов», - говорилось в отчете американской военной разведки [11, с. 53; 12].

В Вашингтоне активно работали по украинскому направлению, стремясь обеспечить страну всем необходимым для скорейшего разоружения. В марте 1992 г. в отчете по итогам поездки на Украину сенатор Р. Лугар отмечал, что США должны установить особый уровень финансирования для демонтажа и уничтожения ракет, расположенных на территории страны. Правда, только после того, как CHB-1 и ДНЯО будут Украиной ратифицированы [20].

Важно отметить, что Вашингтон планировал оказывать финансовую помощь, а не занимать роль посредника в диалоге между Россией и Украиной, о чем в мае 1993 г. заявил посол по особым поручениям С. Тэлбот. «Он [Кравчук] пожелал астрономическую сумму в миллиарды долларов в качестве “компенсации” за ракеты, а также американское обещание, что мы будем расценивать нападение на Украину как нападение на США - почти такие же гарантии безопасности, как даны нашим ближайшим союзникам. Это обязало бы нас выступить на стороне Украины в случае возникновения конфликта между ней и Россией из-за ядерного оружия или по какому-либо иному поводу. Я сказал Кравчуку, что самое большее, что мы можем сделать, - это помочь финансово в возвращении боеголовок в Россию... в обмен на московские гарантии, подкрепленные США, что Россия будет уважать независимость Украины» [24, с. 79].

В целом США планировали оказать Украине помощь в размере 175 млн долл., включая 135 млн долл. на поддержку мероприятий по ликвидации ядерного оружия [25]. «Это однозначно было в интересах Украины, поскольку они понимали, что для своей собственной безопасности им необходимо избавиться от ядерного оружия, наличие которого могло спровоцировать хаос», - вспоминал Р. Лугар [3]. Позиция Вашингтона на переговорах с Киевом заключалась в том, что США не могут обеспечить ему помощь до подписания всех необходимых договоров - Украина должна ратифицировать CHВ-1 и ДНЯО еще на стадии подготовки к демонтажу. 
Американское предложение такой скромной помощи вызывало недовольство украинских политиков. Рассчитывая на многомиллиардный «мирный дивиденд», они пытались найти альтернативные варианты переработки ядерной начинки ракет, в частности, через корпорации «Вестингхауз» и «Дженерал Атомик». Последние моментально согласились построить нужные производственные мощности на территории Украины, чтобы переработать весь ядерный материал и реализовать его на рынке [5, с. 127]. Привлечение новых игроков в процесс разоружения угрожало осложнить и без того непростую ситуацию. С. Тэлботт отмечал, что именно из-за действий украинской стороны США неизменно склонялись к позиции Кремля, поскольку российские дипломаты были более понятны официальному Вашингтону, чем украинские националисты [24, с. 79].

Как отмечалось, вопрос собственности и сохранения ядерного оружия разделил политический истеблишмент Украины на две противоборствующие группы - тех, кто стремился так или иначе сохранить ядерный потенциал, и тех, кто был уверен, что наилучшим выходом для страны будет избавиться от столь разрушительного наследства.

К первому «проядерному» лагерю относились националистически настроенные политики, которые отрицали необходимость следовать в фарватере Москвы и требовали развернуть внешнюю политику в сторону Европы, поскольку в противном случае безъядерная Украина рискует стать зависимой от России. Основу этой группы составляли депутаты Верховной Рады от партии «Народный Рух Украины», некоторые правительственные чиновники (А. Бутейко, И. Бижан), военные (В. Толубко), ученые Академии Наук Украины, многие из которых состояли в специальных депутатских рабочих группах, например, в двух группах Ю. Костенко, которые были созданы для проработки вопросов, связанных с обеспечением национальной безопасности и решением вопросов ратификации соглашений СНВ-1 и ДНЯО [5, с. 89].

Эта часть украинских политиков не считала нужным избавляться от столь ценного в денежном плане актива, поскольку, во-первых, бюджет Украины переживал нелегкие време- на, и, во-вторых, они опасались, что Россия не уничтожит ядерное оружие, а развернет его на своей территории, ввиду чего группа военных предлагала оставить себе 46 ракет СС-24 в качестве страховки [12].

План по сохранению ядерного оружия подразумевал не только использование ракет как щита от потенциальной российской агрессии, но и как «разменной карты» для западных стран, которые опасались ядерной Украины. Ликвидация оружия, по мнению членов группы, должна была стать своеобразным залогом при вступлении в западные структуры - НАТО и/или ЕС. Костенко считал, что «последняя боеголовка должна быть вывезена в тот день, когда Украина станет членом системы европейском безопасности» [5, с. 98].

Понимая опасения Запада, сторонники ядерной Украины искали возможность получить для страны уникальный статус «переходного ядерного государства» или «временной ядерной державы», но безуспешно. В начале января 1993 г. заместитель министра иностранных дел Украины Б. Тарасюк отправился в Вашингтон, чтобы узнать мнение США по вопросу «особого статуса» для Украины [2, c. 64] и уточнить детали по американо-российскому соглашению о продаже 500 т НОУ, включая гарантии, что Россия переработает ядерные материалы, а не оставит их для перевооружения своей армии. «У нас нет причин сомневаться в том, что Россия выполнит свои обязательства», - говорилось в ответе госдепартамента на вопросы Тарасюка. При этом об «особом ядерном статусе» речи не шло [15].

«Антиядерную» российско-американскую позицию на Украине поддерживала группа политиков, в которую входили президент Л. Кравчук, руководитель Службы безопасности Украины Е. Марчук, министр иностранных дел А. Зленко, представители администрации президента, военные и часть депутатов Верховной Рады (С. Головатый, В. Измалков и др.), а также члены рабочей группы по вопросам разоружения, которая была создана 17 февраля 1992 г. в противовес парламентской группе [5, с. 48]. Все они считали, что передача ядерного вооружения в Россию в обмен на «мирный дивиденд» станет благом для Украины с точки зрения международного 
имиджа, безопасности страны и экономической выгоды.

Сторонники вывоза ядерного оружия в Россию отмечали тот факт, что Договор о нераспространении ядерного оружия (ДНЯО) подписали почти все государства мира, и отказ присоединиться к нему ради сохранения ядерной мощи мог привести к международной изоляции практически нищей страны с пятидесятимиллионным населением. Ядерное оружие, по их мнению, угрожало стать слишком дорогой обузой для Украины, которое не только съедает часть бюджета (Украине требовалось порядка 1 млрд долл. ежегодно в течение 7 лет на выполнение обязательств по «программе Нанна - Лугара» [5, с. 73]) и несет в себе потенциальные риски «второго Чернобыля», но и представляет страну в качестве агрессивного националистического государства. К тому же серьезные опасения внушал тот факт, что все ракеты были изготовлены на российских предприятиях и должны были регулярно вывозиться в Россию на техническое обслуживание, а иначе «уже через 5-10 лет этим оружием нельзя будет воспользоваться» [22].

Как отмечалось, на уровне правительства вопрос передачи ядерного оружия в Россию на бумаге решался достаточно оперативно, поскольку Кравчук поставил свою подпись под всеми необходимыми документами и регулярно давал личные обещания выполнить все обязательства по ДНЯО на встречах с президентами США и России. Однако практическая реализация программы застопоривалась из-за регулярных отказов Верховной Рады ратифицировать подписанные президентом договоренности, считая их невыгодными и противоречащими украинским национальным интересам. Более того, представителям Рады часто удавалось «продавить» свою точку зрения и на уровне исполнительной власти. Так, 11 декабря 1992 г. все иностранные посольства в Киеве получили меморандум украинского МИД, где Украина назначала себя собственницей «всех компонентов ядерных боеголовок», что было расценено в мире как дипломатическая игра слов с целью оставить это опаснейшее оружие на своей территории [19].

Внутреннее давление особенно четко прослеживалось в непоследовательности за- явлений и действий Л. Кравчука. Так, сразу же после принятия Радой 24 октября 1991 г. документа о безъядерном статусе Украины [7] он заявил: «Я против того, чтобы перемещать ядерное оружие с территории на территорию. Мы не собираемся раздеться догола и безразлично смотреть, как наши соседи наращивают вооружения» [9]. 6 декабря 1992 г. в парламентской газете «Голос Украины» вышло интервью Кравчука, в котором он подчеркнул, что разоружение по Лиссабонскому протоколу должно осуществляться пропорционально и параллельно с четырьмя экссоветскими республиками и с учетом права собственности Украины на материальные ценности из разобранных ядерных ракет. 3 января 1993 г. Кравчук заявил, что CHB-1 не налагает обязательств на Украину и не распространяется на ее территорию. В итоге 22 января 1993 г. в Минске под нажимом членов «группы Костенко», вернувшихся с переговоров из Москвы, он отказался ставить подпись под уставом СНГ, который включал и вопрос ликвидации ядерного вооружения под контролем России [5, с. 179].

Демарши украинского президента на фоне его позитивных заявлений о желании избавиться от ядерного оружия становились все более привычным явлением для Вашингтона. «Кравчук использует ядерный вопрос, чтобы продавить свою позицию в СНГ и на международной арене», - говорилось в отчете военной разведки США [12]. «Кравчук находится в состоянии борьбы с Россией и использует ядерное оружие для привлечения внимания к своей стране и поддержки со стороны Запада», - уверяли американские эксперты в Пентагоне [13].

Руководители России и США понимали, что националистические «проядерные» группировки в Украине стремились заставить Кравчука отказаться от своих обещаний сделать Украину «безъядерной», но верили ему лично в отношении выполнения международных обязательств по разоружению страны [12]. Об этом, в частности, говорили президенты Дж. Буш и Б. Ельцин 1 февраля 1992 г.:

Дж. Буш: Вокруг Кравчука существует группа, которая смотрит на ситуацию иначе, чем он? Они хотят отделиться от СНГ и подталкивают его к этому?» 
Б. Ельцин: «Да, существует группировка в Верховном Совете. Это ультра-националисты и их имя "Рух". У них есть свои люди, но нет большинства в Раде. "Рух" оказывает постоянное давление на президента. Я уважаю позицию Кравчука, он не уступает. Это его искренняя позиция» [18].

15 января 1993 г. на встрече с Ельциным Кравчук твердо заявил, что «все ядерные боеприпасы будут ликвидированы в соответствии с достигнутыми договоренностями и разработанными графиками под международным контролем». Эта позиция дала возможность правительствам РФ и Украины сформировать специальные делегации и начать переговоры по урегулированию вопросов, связанных с реализацией CHB-1. Российскую группу возглавил Ю. Дубинин, а украинскую - Ю. Костенко [2, с. 47].

Атмосфера трех раундов переговоров (26 января 1993 г. в Ирпене, 24 февраля в Москве и 13 августа в Киеве) была очень накаленной. Результаты их напрямую зависели от принадлежности членов украинской делегации к депутатской или правительственной рабочим группам. В результате на первых двух встречах украинская делегация, возглавляемая Ю. Костенко, не смогла прийти к взаимопониманию с российскими коллегами.

Так, в Ирпене делегаты прямым текстом провозгласили «право собственности» Украины на ядерные боезаряды, игнорируя подписи своего президента под документами с обязательствами стать «безъядерной страной». Украинская делегация требовала от российской стороны обсудить размер компенсации за вывезенное ранее тактическое ядерное оружие, решить вопрос обслуживания украинских ядерных зарядов специалистами с российских заводов-изготовителей и поддержать Украину на ее пути к безъядерному статусу, но с корректировкой на украинские финансовые интересы. Российская сторона на тот момент не имела полномочий вести переговоры с «ядерным государством», и поэтому обсуждение отложили до ответного визита в Москву.

На московских переговорах ситуация не изменилась. Ю. Костенко при этом открыто заявил своему российскому коллеге Ю. Дубинину: «Да, Леонид Кравчук, конечно, остается президентом. Но не думайте, что он в состоянии добиться всего того, что хочет, выполнить все, под чем подписался» [2, с. 61]. Одновременно подчеркивалось, что конституция Украины не имела четких границ, определявших полномочия президента при подписании и реализации договоров с другими странами.

Прогресса удалось достичь лишь на переговорах в августе 1993 г. в Киеве, когда Ю. Костенко отправился на месяц в США для посещения ядерных лабораторий. Тогда место руководителя делегации занял вице-премьер В. Шмаров, а военное направление вместо И. Бижана досталось начальнику Генерального штаба А. Лопате. В течение двух дней российская и украинская стороны договорились о ликвидации всех ядерных боезарядов на территории Украины и порядке взаиморасчетов. По соглашению все ядерное оружие бывшего СССР, оставшееся на территории Украины, передавалось в Россию в обмен на «мирный дивиденд».

«О праве собственности Украины на ядерное оружие речи не шло», - писал Дубинин [2, с. 66]. Единственный вопрос, который был оставлен на обсуждение президентам это сроки вывода ядерного арсенала. Данный вопрос был успешно решен на встрече президентов России и Украины в Массандре (Ялта), по итогам которой было предписано вывезти ядерное оружие в Россию в течение 24 месяцев после ратификации Украиной договора CHB-1.

Однако ялтинские договоренности так и не вступили в силу по причине фальсификации документов со стороны одного из советников президента Украины, А.Д. Бутейко. 21 сентября 1993 г. МИД России выступил с официальным заявлением, суть которого сводилась к тому, что в газете «Киевские ведомости» от 9 сентября 1993 г. было опубликовано фото конфиденциального, не подлежащего публикации договора в Массандре. Дубинин писал, что Бутейко, «воспользовавшись тем, что документы оказались в его руках, внес от руки два корректива в текст, что полностью изменило его содержание». Бутейко вычеркнул слово «всех» в предложении о вывозе боезарядов с Украины на территории Российской Федерации и после слов «стратегических ядерных сил» вставил 
слова «подпадающих под договор». В связи с этим Россия была вынуждена признать «Протокол о вывозе всех ядерных боезарядов...» недействительным и аннулировать все соглашения $[2$, с. 70$]$.

Таким образом, борьба группировок внутри политической элиты Украины мешала довести процесс разоружения до логического финала. 18 ноября 1993 г. Верховная Рада рассмотрела и ратифицировала СНВ-1 и Лиссабонский протокол, включив в него ряд поправок, неприемлемых для России и США. В частности, парламент провозгласил государственную собственность Украины на ядерное оружие, что не могло быть и не было принято другими сторонами процесса.

В конечном итоге попавший в сложное положение Л. Кравчук пообещал американской и российской сторонам повторно внести в Раду вопрос о ратификации ДНЯО и договора СНВ-1 после переизбрания украинского парламента в марте 1994 года. Вскоре новая Рада действительно ратифицировала ДНЯО и договор CHВ-1, согласившись таким образом на условия, предложенные Москвой и Вашингтоном [8].

Точка в ядерном разоружении Украины была поставлена в ночь с 4 на 5 декабря 1994 г. в Будапеште на Совещании по безопасности и сотрудничеству в Европе на высшем уровне. Именно там Украина подписала Будапештский меморандум (или «Меморандум о гарантиях безопасности в связи с присоединением Украины к Договору о нераспространении ядерного оружия») в качестве государства, «не обладающего ядерным оружием». Ю. Дубинин вспоминает, что в 2004 г. он интересовался у члена американской делегации Дж. Коллинза о том, как удалось убедить Кравчука подписать меморандум. «Трудно было, очень трудно, - ответил Коллинз. - В Будапеште украинские руководители увидели, что этот шанс будет приветствоваться во всем мире и послужит Украине больше, чем сопротивление желанию мирового сообщества» [2, с. 78$]$.

По сути подписание Будапештского меморандума и отказ от статуса ядерного государства вывели Украину из состояния международной изоляции. Вследствие этого МВФ и Всемирный банк подписали ряд договорен- ностей с украинским правительством о финансовой помощи. Но самое главное, в результате удалось снизить военно-политическую напряженность в регионе, о чем достаточно ясно выразился сенатор С. Нанн: «Я думаю, что если бы они тогда [украинские политики] не приняли это мудрое решение, сохранили бы ядерное оружие, то военный конфликт между двумя странами на этой стадии был бы абсолютно неизбежным» [4].

1 июня 1996 г. Украина стала безъядерным государством, отправив последние ядерные боеголовки в Россию. В самой Украине были ликвидированы 130 пусковых установок ракет СС-19 и 111 ракет этого типа, 4 учебные шахты жидкостных ракет различных типов и 13 пунктов управления пуском [21]. В итоге общие расходы по ядерному разоружению Украины составили более 850 млн долл., то есть намного больше, чем планировалось изначально [23, с. 408].

Результаты. Таким образом, в начале 1990-х гг. в рамках «программы Нанна - Лугара» США и РФ объединили свои усилия по вопросу вывода ядерного оружия с Украины и превращению ее в «безъядерную державу». Вашингтон при этом исходил из того, что оставлять ядерное оружие на Украине нельзя по причине возможности попадания каких-то его элементов в руки «стран-изгоев» или террористов, а передача боеголовок России обеспечит дешевизну и безопасность их ликвидации. Москва считала, что Киев просто технически не сможет решить задачу ликвидации боеголовок, а кроме того, опасалась, что у Украины может возникнуть опасный соблазн поставить ядерные ракеты на вооружение своей армии. Сама украинская политическая элита оказалась расколотой по данному вопросу. «Проядерная» группировка, имевшая большинство в Верховной Раде, считала, что надо настаивать на собственности Украины на ядерные ракеты, что облегчило бы ей вступление в ЕС и НАТО, а также гарантировало «мирный дивиденд». Представители «антиядерной» группировки, базировавшейся в основном в исполнительной ветви власти, опасались международной изоляции Украины, что в стратегическом отношении могло принести ей еще больший ущерб. Поскольку президент Л. Кравчук, несмотря на давление США, за- 
нимал двойственную позицию, то все попытки Москвы договориться с Киевом об условиях реализации «программы Нанна - Лугара» заходили в тупик. Только изменение баланса политических сил на Украине в начале 1994 г. позволило президенту ратифицировать необходимые документы и подписать Будапештский меморандум, после чего началась практическая фаза ликвидации украинского стратегического ядерного оружия, завершившаяся в 1996 году.

\section{СПИСОК ЛИТЕРАТУРЫ}

1. Будапештский меморандум или паралич воли. Тактика без стратегии. - Электрон. текстовые дан. - Режим доступа: https://farwater.net/istoriya-i-mify/ taktika-bez-strategii (дата обращения: 11.03.2020). - Загл. с экрана.

2. Дубинин, Ю. В. Дипломатический марафон / Ю. В. Дубинин. - М. : АвиаРус-XXI, 2005. - 351 с.

3. Интервью сенатора Ричарда Лугара русской службе «Голос Америки». - 2015. - 27 марта. - Электрон. текстовые дан. - Режим доступа: http:// www.golos-ameriki.ru/a/lugar-interview/2696848.html (дата обращения: 02.12.2019). - Загл. с экрана.

4. Интервью сенатора США Сэма Нанн для радиостанции «Эхо Москвы». - 2016. - 26 февр. Электрон. текстовые дан. - Режим доступа: http:// echo.msk.ru/programs/beseda/1719620-echo/ (дата обращения: 02.12.2019). - Загл. с экрана.

5. Костенко, Ю. Історія Ядернного Роззброэння Украіны / Ю. Костенко. - Киев : Ярославів вал, 2015. $-464 \mathrm{c}$.

6. Маслин, Е. Ядерное оружие и контроль за его нераспространением / Е. Маслин // Обозреватель. - 1994. - № 3-4. - Электрон. текстовые дан. Режим доступа: http://observer.materik.ru/observer/ N03-4_94/3-4_06.HTM (дата обращения: 02.12.2019). Загл. с экрана.

7. Про без'ядерний статус України. Верховна Рада України : заява від 24.10.1991 № 1697-ХІІ. - Электрон. текстовые дан. - Режим доступа: http:// zakon5.rada.gov.ua/laws/show/1697-12 (дата обращения: 02.12.2019). - Загл. с экрана.

8. Про приєднання України до Договору про нерозповсюдження ядерної зброї від 1 липня 1968 року Верховна Рада України : закон від 16.11.1994 № 248/94-ВР. - Электрон. текстовые дан. Режим доступа: http://zakon5.rada.gov.ua/laws/ show $/ 248 / 94-\% \mathrm{D} 0 \% \mathrm{~B} 2 \% \mathrm{D} 1 \% 80$ (дата обращения: 02.12.2019). - Загл. с экрана.

9. Скачко, В. Украинский парламент утвердил оборонную стратегию республики: она предпола- гает наличие собственных армии и флота / В. Скачко // Независимая газета. - 1991. -24 окт.

10. Тристороння заява Президентів України, США та Росії (укр/рос). Україна, Російська Федерація, США : заява, Міжнародний документ від 14.01.1994. - Электрон. текстовые дан. - Режим доступа: http://zakon5.rada.gov.ua/laws/show/998_300 (дата обращения: 02.12.2019). - Загл. с экрана.

11. Чумак, В. Программа Нанна - Лугара на Украине / В. Чумак, С. Галака // Ядерный контроль. - 2000. - № 5. - С. 52-61. - Электрон. текстовые дан. - Режим доступа: http://pircenter.org/media/ content/files/9/13508142980.pdf (дата обращения: 11.03.2020). - Загл. с экрана.

12. Cable, Defense Intelligence Agency, Washington, "Defense Intelligence Report ODB 2792, Ukraine - Nuclear Withdrawal Suspension" // The National Security Archive, Nunn-Lugar Collection. - 1992. - Mar. 27. - Electronic text data. Mode of access: https://nsarchive2.gwu.edu/NuclearWeapons-and-Ukraine/Doc-13-DIA-cable-Ukrainenuclear-withdrawal-suspension-1992-03-27.pdf (date of access: 10 January 2020). - Title from screen.

13. Cable, Defense Intelligence Agency Washington, "Dynamics of Change in Eurasia" [Excerpts] // The National Security Archive, Nunn-Lugar Collection. - 1992. - May 5. - Electronic text data. Mode of access: http://nsarchive.gwu.edu/NSAEBB/ NSAEBB447/1992-05-09\%20Cable,\%20Defense $\% 20$ Intelligence $\% 20$ Agency $\% 20$ Washington, $\% 20$ Dynamics\%20of\%20Change\%20in\%20 Eurasia\% 20[Excerpts].PDF (date of access: 2 December 2019). Title from screen.

14. Congressional Research Service. Economic Crisis in Ukraine: Dangers and Opportunities. CRS Report for Congress. - 1994. - Aug. 18. - Washington, D.C. : GPO, 1994. -25 p.

15. Department of State, Talking Points and NonPaper for Meeting with Ukrainians // The National SecurityArchive, Nunn-Lugar Collection. Circa. - 1993. Dec. 3. - Electronic text data. - Mode of access: http:// nsarchive.gwu.edu/NSAEBB/NSAEBB 447/1993-12$03 \% 20$ Talking\%20 Points, \%20 Department $\% 20$ of $\% 20$ State.pdf (date of access: 2 December 2019). Title from screen.

16. Information Memorandum for Brent Scowcroft from Ed. A. Hewett, "Ukrainian Approach to Defense Matters" // The National Security Archive, Nunn-Lugar Collection. - 1991. - Nov. 8. - Electronic text data. - Mode of access: http://nsarchive.gwu.edu/ N S A E B B / N S A E B B 4 4 7/1991-11 08\%20Information\%20 Memorandum\%20for\%20 Brent $\% 20$ Scowcroft \%20from\%20Ed.\%20A.\%20 Hewett,\%20Ukrainian \%20Approach\%20to\%20 Defense\%20Matters.PDF (date of access: 2 December 2019). - Title from screen. 
17. Memorandum from Philip Zelikow to Graham Allison, Robert Blackwill, Al Carnesale, Ash Carter, bill Hogan, "Harvard Discussion with Kravchuk on Nuclear Weapons" // The National Security Archive, Nunn-Lugar Collection. - 1991. - Sep. 30. - Electronic text data. - Mode of access: http://nsarchive.gwu.edu/ N S A E B B / N S A E B B $447 / 1991$ - 09 $30 \% 20$ Memorandum $\% 20$ from $\% 20 \mathrm{Philip} \% 20$ Zelikow\%20to\%20 Graham\%20Allison,\%20Robert $\% 20$ Blackwill, \%20Al\%20Carnesale, $\% 20$ Ash $\% 20$ Carter,\%20 Bill\%20Hogan,\%20\%E2\%80\%9Harvard\% 20 Discussion $\% 20$ with $\% 20 \mathrm{Kravchuk} \% 20$ on $\%$ $20 \mathrm{Nuclear} \% 20$ Weapons\%E2\%80\%9D.PDF (date of access: 2 December 2019). - Title from screen.

18. Memorandum ofConversation between President Bush and President Yeltsin // The National Security Archive, Nunn-Lugar Collection. - 1992. - Feb. 1.Electronic text data. - Mode of access: http:// nsarchive.gwu.edu/NSAEBB/NSAEBB447/1992-0201\%20Memorandum $\% 20$ of $\% 20$ Conversation $\% 20$ betwe en $\% 20$ President $\% 20$ Bush $\% 20$ and $\% 20$ President $\% 20$ Yeltsin.PDF (date of access: 2 December 2019). - Title from screen.

19. Memorandum of the Ministry of Foreign Affairs of Ukraine on Clarifying Ukraine's Nuclear Policy. - 1992. Dec. 11. - Electronic text data. - Mode of access: http:// digitalarchive.wilsoncenter.org/document/119817 (date of access: 2 December 2019). - Title from screen.

20. Press Conference, Senator Sam Nunn and Richard Lugar, "report from their Tour of the Russian Republics" // The National Security Archive, NunnLugar Collection. - 1992. - Nov. 25. - Electronic text data. - Mode of access: http://nsarchive.gwu.edu/ NSAEBB/NSAEBB447/1992-11-25\%20Press\%20 Conference, $\% 20$ Senator $\% 20$ Sam $\% 20$ Nunn $\%$ 20and\%20Senator\%20Richard\%20Lugar,\%20 Report\% 20 from $\% 20$ their $\% 20$ Tour $\% 20$ of $\%$ 20the $\% 20$ Russian $\% 20$ Republics.PDF (date of access: 2 December 2019). - Title from screen.

21. Putzel, M. US says Ukraine to give up atom arms / M. Putzel // The Boston Globe. - 1994. January 11. - P. 5.

22. Report to Vitaly Kataev on the State of Nuclear Weapons in Ukraine // The National Security Archive, Nunn-Lugar Collection. - 1994. - Sep. 16. - Electronic text data. - Mode of access: http://nsarchive.gwu.edu/ NSAEBB/NSAEBB447/1994-09-16\%20Report $\% 20$ by $\% 20$ Vitaly $\% 20$ Kataev $\% 20$ on $\% 20$ the $\% 20$ state $\% 20$ of $\% 20$ Nuclear $\% 20$ Weapons \%20in $\% 20$ Ukraine.pdf (date of access: 2 December 2019). - Title from screen.

23. Shields, J. Dismantling the Cold War / J. Shields, W. Potter. - L. ; Cambridge : MIT Press, 1997. $-450 \mathrm{c}$.

24. Talbott, S. The Russian Hand: A Memoir of Presidential Diplomacy/ S. Talbott. - N. Y. : Random House, 2003. -512 c.
25. Under Secretary of Defense Frank Wisner Letter to Senator Sam Nunn // The National Security Archive, Nunn-Lugar Collection. - 1993. - Nov. 17. Electronic text data. - Mode of access: http:// nsarchive.gwu.edu/NSAEBB/NSAEBB447/1993-1117\%20Letter\%20from\%20Wisner\%20to\%20Nunn.pdf (date of access: 2 December 2019). - Title from screen.

\section{REFERENCES}

1. Budapeshtskiy memorandum ili paralich voli. Taktika bez strategii [The Budapest Memorandum or Paralysis of the Will. Tactics Without Strategy]. URL: https://farwater.net/istoriya-i-mify/ taktika-bez-strategii (accessed 11 March 2020).

2. Dubinin Yu. Diplomaticheskiy marafon [The Diplomatic Marathon]. Moscow, AviaRus-XXI Publ., 2005. 351 p.

3. Intervyu senatora Richarda Lugara russkoy sluzhbe «Golos Ameriki» [Interview with Senator Richard Lugar to the "Voice of America" Russian Service]. 2015, March 27. URL: http://www.golosameriki.ru/a/lugar-interview/2696848.html (accessed 2 December 2019).

4. Intervyu senatora SShA Sema Nann dlya radiostantsii «Ekho Moskvy» [US Senator Sam Nunn Interviews for "Ekho Moskvy" Radio]. 2016, February 26. URL: http://echo.msk.ru/programs/ beseda/1719620-echo (accessed 2 December 2019).

5. Kostenko Yu. Istoriya Yadernnogo Rozzbroennya Ukrainy [History of Nuclear Disarmament of Ukraine]. Kiev, Yaroslaviv val Publ., 2015. $464 \mathrm{p}$.

6. Maslin E. Yadernoe oruzhie i kontrol za ego nerasprostraneniem [Nuclear Weapons and Control of Its Non-Proliferation.]. Obozrevatel [Observer], 1994, no. 3-4. URL: http://observer.materik.ru/observer/N034_94/3-4_06.HTM (accessed 2 December 2019).

7. Pro bezyaderniy status Ukraini. Verkhovna Rada Ukraini : zayava vid 24.10.1991 № 1697-XII. [About the Nuclear-Free Status of Ukraine. Statement of the Verkhovna Rada of Ukraine no. 1697-XII, October 24, 1991]. URL: http://zakon5.rada.gov.ua/ laws/show/1697-12 (accessed 2 December 2019).

8. Pro priiednannya Ukraini do Dogovoru pro nerozpovsyudzhennya yadernoi zbroi vid 1 lipnya 1968 roku Verkhovna Rada Ukraini : zakon vid 16.11.1994 № 248/94-VR [Law no. 248/94-BP Dated October 16, 1994 of the Verkhovna Rada of Ukraine on Ukraines Accession to the Treaty on the NonProliferation of Nuclear Weapons of July 1, 1968]. URL: http://zakon5. rada.gov.ua/laws/show/248/94$\% \mathrm{D} 0 \% \mathrm{~B} 2 \% \mathrm{D} 1 \% 80$ (accessed 2 December 2019).

9. Skachko V. Ukrainskiy parlament utverdil oboronnuyu strategiyu respubliki: ona predpolagaet 
nalichie sobstvennykh armii i flota [The Ukrainian Parliament Approved the Republics Defense Strategy: It Implies the Existence of Its Own Army and Navy]. Nezavisimaya gazeta, 1991, October 24.

10. Tristoronnya zayava Prezidentiv Ukraini, SShA ta Rosii (ukr/ros). Ukraina, Rosiyska Federatsiya, SShA : zayava, Mizhnarodniy dokument vid 14.01.1994 [Trilateral Statement by the Presidents of Ukraine, the Russian Federation and the USA. International Document Dated January 14, 1994]. URL: http://zakon5.rada.gov.ua/laws/show/998_300 (accessed 2 December 2019).

11. Chumak V., Galaka S. Programma NannaLugara na Ukraine [The Nunn-Lugar Program in Ukraine]. Yaderny Kontrol, 2000, no. 5, pp. 52-61. URL: http://pircenter.org/media/content/files/9/ 13508142980.pdf(accessed 11 March 2020).

12. Cable, Defense Intelligence Agency, Washington, "Defense Intelligence Report ODB 27-92, Ukraine - Nuclear Withdrawal Suspension". The National Security Archive, Nunn-Lugar Collection. 1992, March 27. URL: https:// nsarchive2.gwu.edu/Nuclear-Weapons-andUkraine/Doc-13-DIA-cable-Ukraine-nuclearwithdrawal-suspension-1992-03-27.pdf (accessed 10 January 2020).

13. Cable, Defense Intelligence Agency Washington, "Dynamics of Change in Eurasia [Excerpts]". The National Security Archive, NunnLugar Collection. 1992, May 5. URL: http://nsarchive. gwu.edu/NSAEBB/NSAEBB447/1992-05-09\%20 Cable, \%20Defense \%20Intelligence\%20Agen cy $\% 20$ Washington, $\% 20$ Dynamics $\% 20$ of\% 20 Change\%20in\%20Eurasia\%20[Excerpts].PDF (accessed 2 December 2019).

14. Congressional Research Service. Economic Crisis in Ukraine: Dangers and Opportunities. CRS Report for Congress. 1994, August 18. Washington, D.C., GPO, 1994. 25 p.

15. Department of State, Talking Points and NonPaper for Meeting with Ukrainians. The National Security Archive, Nunn-Lugar Collection. Circa 1993, December 3. URL: http://nsarchive.gwu.edu/NSAEBB/ NSAEBB447/1993-12-03\%20Talking\%20Points, $\% 20$ Department $\% 20$ of $\% 20$ State.pdf (accessed 2 December 2019).

16. Information Memorandum for Brent Scowcroft from Ed. A. Hewett, "Ukrainian Approach to Defense Matters". The National Security Archive, Nunn-Lugar Collection. 1991, November 8. URL: http://nsarchive.gwu.edu/NSAEBB/NSAEBB447/ 1991-11-08\%20Information \%20Memorandum $\% 20$ for $\% 20$ Brent $\% 20$ Scowcroft $\% 20$ from $\% 20$ Ed.\%20A.\%20Hewett,\%20Ukrainian\%20A pproach\%20to\%20 Defense\%20Matters.PDF (accessed 2 December 2019).
17. Memorandum from Philip Zelikow to Graham Allison, Robert Blackwill, Al Carnesale, Ash Carter, bill Hogan, "Harvard Discussion with Kravchuk on Nuclear Weapons". The National Security Archive, Nunn-Lugar Collection. 1991, September 30. URL: http://nsarchive.gwu.edu/NSAEBB/NSAEBB447/ 1991-09-30\%20Memorandum\%20from\%20Philip \%20Zelikow\%20to\%20Graham\%20Allison, \%20 Robert\%20 Blackwill,\%20A1\%20Carnesale,\%20 Ash $\% 20$ Carter, $\% 20$ Bill\%20Hogan, $\% 20 \%$ E2\%80\%9C Harvard\%20Discussion \% 20with \%20Kravchuk $\% 20$ on $\% 20$ Nuclear $\% 20$ Weapons $\%$ E2\%80\%9D.PDF (accessed 2 December 2019).

18. Memorandum of Conversation Between President Bush and President Yeltsin. The National Security Archive, Nunn-Lugar Collection. 1992, February 1. URL: http://nsarchive.gwu.edu/NSAEBB/ NSAEBB447/1992-02-01\%20Memorandum $\% 20$ of $\% 20$ Conversation $\% 20$ between $\% 20$ Pres ident $\% 20$ Bush $\% 20$ and $\% 20$ President $\% 20$ Yeltsin.PDF (accessed 2 December 2019).

19. Memorandum of the Ministry of Foreign Affairs of Ukraine on Clarifying Ukraines Nuclear Policy. 1992, December 11. URL: http://digitalarchive. wilsoncenter.org/document/119817 (accessed 2 December 2019).

20. Press Conference, Senator Sam Nunn and Richard Lugar, "Report from Their Tour of the Russian Republics". The National Security Archive, NunnLugar Collection. 1992, November 25. URL: http:// nsarchive.gwu.edu/NSAEBB/NSAEBB447/1992-11$25 \% 20$ Press $\% 20$ Conference, $\% 20$ Senator $\% 20$ Sam $\% 20$ Nunn $\% 20$ and $\% 20$ Senator $\% 20$ Richard $\% 20$ Lugar, $\% 20$ Report $\% 20$ from $\% 20$ their\%20Tour $\% 20$ of $\% 20$ the \%20Russian\%20Republics.PDF (accessed 2 December 2019).

21. Putzel M. US Says Ukraine to Give Up Atom Arms. The Boston Globe, 1994, January 11, p. 5.

22. Report to Vitaly Kataev on the State of Nuclear Weapons in Ukraine. The National Security Archive, Nunn-Lugar Collection. 1994, September 16. URL: http:// nsarchive.gwu.edu/NSAEBB/NSAEBB 447/1994-09$16 \% 20$ Report $\% 20$ by $\% 20$ Vitaly $\% 20$ Kataev $\% 20$ on $\%$ 20 the $\% 20$ state $\% 20$ of $\% 20$ Nuclear $\% 20$ Weapons $\%$ 20in\%20Ukraine.pdf(accessed 2 December 2019).

23. Shields J., Potter W. Dismantling the Cold War. London, Cambridge, MIT Press, 1997.450 p.

24. Talbott S. The Russian Hand: A Memoir of Presidential Diplomacy. New York, Random House, 2003. $512 \mathrm{p}$.

25. Under Secretary of Defense Frank Wisner Letter to Senator Sam Nunn. The National Security Archive, Nunn-Lugar Collection. 1993, November 17. URL: http://nsarchive.gwu.edu/NSAEBB/NSAE BB447/1993-11-17\%20Letter\%20from\%20 Wisner \%20to\%20Nunn.pdf (accessed 2 December 2019). 


\section{ВОЕННО-ПОЛИТИЧЕСКИЕ КОНФЛИКТЫ ХХ ВЕКА}

\section{Information About the Authors}

Sergey Yu. Shenin, Doctor of Sciences (History), Professor, Department of International Relations and Russian Foreign Policy, Saratov National Research State University named after N.G. Chernyshevsky, Astrakhanskaya St., 83, 410012 Saratov, Russian Federation, shenins@yahoo.com, https://orcid.org/0000-0002-4503-5923

Andrei S. Shenin, Candidate of Sciences (History), Director, Department of Public Administration, Narxoz University, $1^{\text {st }}$ Microdistrict, 81, 050035 Almaty, Republic of Kazakhstan, shenin.andrei@gmail.com, https://orcid.org/0000-0001-8468-4275

\section{Информация об авторах}

Сергей Юрьевич Шенин, доктор исторических наук, профессор кафедры международных отношений и внешней политики России, Саратовский национальный исследовательский государственный университет им. Н.Г. Чернышевского, ул. Астраханская, 83, 410012 г. Саратов, Российская Федерация, shenins@yahoo.com, https://orcid.org/0000-0002-4503-5923

Андрей Сергеевич Шенин, кандидат исторических наук, директор научно-образовательного департамента государственного управления, Университет Нархоз, 1-й микрорайон, 81, 050035 г. Алматы, Республика Казахстан, shenin.andrei@gmail.com, https://orcid.org/0000-0001-8468-4275 